\title{
Design and experimental tests of an Imbert type downdraft gasifier prototype and clean-up system for small-scale biomass-based power generation
}

\author{
Miguel Mendonça*, Victor Mantilla(iD, João Patela(D, Valter Silva(D, and Fernanda ResendeiD
}

Superior de Tecnologia e Gestão de Águeda, Universidade de Aveiro, Aveiro, Portugal

Received: 16 July 2021 / Received in final form: 24 November 2021 / Accepted: 25 November 2021

\begin{abstract}
This paper addresses the design, development and experimental tests of a prototype of fuel gas generation system based on biomass gasification for small-scale applications, around $5 \mathrm{~kW}$. It comprises the small scale downdraft gasifier and the gas cleaning system aiming to clean-up the producer gas to be used in the upstream Internal Combustion Engine (ICE). The design of the downdraft gasifier prototype follows the methodologies that have been reported on the available literature. However, since these methodologies apply to gasifiers with larger rated powers, the adopted methodology is based on the extrapolation of the main parameters used for larger gasifiers design. For runing the ICE the producer gas requires to have a specific gas composition with an acceptable range of impurities. Therefore, a clean-up system was proposed following three stages: in first instance a hot gas clean-up using a cyclone designed to eliminate particles and compounds; then a heat exchanger was used for cooling the gas to condensate tars and water; finally a cold gas clean-up is performed by filtration using two filter steps: the first one using organic material (biomass) and the second one using a polypropylene cartridge filter. Experimental tests were performed using the developed imbert downdraft gasifier prototype, using pellets as feedstock. The preliminary results allow verifying several drawbacks that will difficult an effective integration of the developed prototype for small scale power generation applications based on ICE using low density feedstock.
\end{abstract}

\section{Introduction}

Small-scale power generation based on biomass gasification is atracting an increasing interest as a promising technology of Renewable Energy Source (RES) to provide electricity on remote areas worldwide using the biomass available locally, such as forest residues (dead trees and wood chips) and agriculture residues. Using these biomasses for power generation brings several advantages related with their wide availability, less intermittency and homogeneous distribution, providing several environment and socio-economic benefits, which include the reduction of the carbon dioxide emissions, the local fuel security supply and the reduction of transportation costs [1,2].

In the particular case of Portugal, which has about one third of the territory of forest area, the valorization of biomass associated with its use for electricity generation brings an additional benefit and, therefore, an incentive for reducing both the forest fuel load and the risk of forest fires in rural areas, which have been occurring with increasing

\footnotetext{
* e-mail: mlm@ua.pt
}

frequency in the country [3,4]. The major obstacles to the use of biomass in large-scale energy production lies in tranportation, collection and handling, due to its bulkiness. Because the biomass is spread widely around the country, small-scale power generation systems based on biomass gasification, which can operate close to the places where it is collected,will become more attractive [5].

This feature has been exploited within the framework of the SUBe Project [3,5] aiming the harnessing and valuing the biomass available in the Portuguese rural areas. For this purpose an experimental set-up suitable to be used as a distributed small-scale power generation, either in mobile or stationary applications, using the locally available biomass, has been developed to be used for demonstration purposes. These systems basically consist of a gasifier that produces combustible gas from the biomass gasification process (usually called producer gas or syngas), which is then used as fuel to feed an Internal Combustion Engine (ICE) to drive an electrical generator. Thus, the downdraft gasifier prototype has been designed and developed to be assembled in a small pilot power generation plant rated around $5 \mathrm{~kW}$, which comprises the gasifier prototype and the ICE coupled to a synchronous electrical generator. To work with producer 
gas, the ICE requires minimum tar and particulates concentration. Therefore, the clean-up system was also designed and implemented aiming to reduce the impurities to the acceptable levels required by the upstream ICE.

Thus, this paper presents the design, development and preliminary experimental tests of both the downdraft imbert type gasifier prototype and the clean-up system, which have been intended to integrate the pilot power generation system unit based on biomass gasification that is currently under development within the framework of the SUBe project. Therefore, the design and development of the downdraft gasifier prototype accounts the following main requirements: capability to handle the low density biomass available in forest and rural areas; small dimensions; easy to install and to operate locally.

Gasifiers were widely used in the past in small-scale applications, namely power motor vehicles during second world war [6,7]. Nowadays, small-scale biomass gasification is broadly used in power generation systems in some remote regions of Asian countries, such as India $[8,9]$. Despite downdraft reactors has been studied extensively for biomass gasification in small scale applications, there is still a lot do evolve [10]. The major problem lies in the producing fuel gas from biomass gasification with low tar, required to be used in ICE.

The gasification technologies convert biomass into combustible gaseous fuels by partial oxidation of the biomass at high temperatures. Different gasifiers have been employed in this process, being the main differences among them concerned with how the biomass and oxidizer are moved in the reactor [11]. Fixed bed gasifiers, both the downdraft and updraft types, are well suited for small scale applications. Among them, the downdraft gasifier presents the advantage of low tar generation, due to the effect of the gas passing through a high temperature zone, enabling partial cracking of the tars formed during gasification [12-17]. Also, the downdraft technology owns favourable features for small-scale power generation, allowing the flexible adaptation of the system production to the load, low sensitivity to charcoal dust and tar contents of the fuel, shorter time of ignition and shorter time to reach the operating temperature than the updraft type gasifiers [18]. Therefore the conceptual framework of the downdraft gasifier was adopted withing the framework of the presented research work.

However, the effective use of downdraft based technologies in applications of biomass gasification for power generation presents several challenges, including mainly the production of clean gas for ICE as well as the issues regarding the gas cleaning. Among the gas impurities, tar is the most challenging one, which is difficult to remove to an accepatble range for ICE [19]. The concentration of impurities in the producer gas depends on many factors. However both the reactor specifications and the gasification conditions are highlighted as the major factors that control the producer gas quality. In downdraft gasifiers, the temperature plays a key role within this framework. According to [20], the tar concentration is mainly affected by the gasification temperature. Thus, low temperatures will contribute to high tar concentrations and low yield of $\mathrm{CO}$ and $\mathrm{H}_{2}$, while the high temperature leads to high yield of $\mathrm{CO}$ and $\mathrm{H}_{2}$ with low tar concentration. The tar yield from the gasification bellow $1000{ }^{\circ} \mathrm{C}$ is significantly higher than the acceptable range, thus requiring stringent gas cleaning features for power generation applications using ICE [7]. Therefore, in this paper, the formation of tar contents should be controlled by setting up the temperature conditions suitable to perform the required thermal decomposition (above $1000^{\circ} \mathrm{C}$ ). This is a key criterion to be accounted during the design stage of the downdraft gasifier prototype in order to give the required reactor specifications.

Most gasifier development reported in literature still follows the design methodology described in the Solar Energy Research Institute (SERI) report [21], which summarize the Swedish experience in the development of gasifiers in the period 1939-1945 [22]. However, the presented design methodologies address downdraft gasifiers with rated powers larger than the one intended for the gasifier prototype. According to [23], only a few reaserach works have been published. Also, these works follow the guidelines presented in the SERI report [21] to develop downdraft gasifiers with small ratings for agricultural pumping application, such as $3,7 \mathrm{~kW}$ and $5 \mathrm{hp}$, as presented in [24,25], respectively. More recently small downdrafts gasifiers were developed, as presented in [23] for domestic cookstoves.

Therefore, the main guidelines reported on the available literature, regarding this research field, were also followed to establish a suitable design methodology for sizing the imbert type downdraft gasifier prototype to be developed within the framework of this paper. Also, the data points obtained by extrapolation in [23], regarding the throat or heart dimater, were used to support the design methodology of the small imbert type downdraft gasifier, rated around $5 \mathrm{~kW}$, intended for small power application with ICE. Design data to cover this range for power applications with ICE is lacking, thus requiring the development and assessment of design methodologies, fabrication and testing for both this kind of gasifiers and this kind of applications. Thus, a new Imbert type downdraft gasifier rated around $5 \mathrm{~kW}$ was designed, developed and tested experimentally within the framework of this paper.

\section{Gasifier design and development}

\subsection{Gasification process}

Downdraft gasifiers are the most widespread reactors for biomass and carbon conversion for small-scale power generation applications using ICE [10]. According to [26], downdraft gasifiers are more suitable for small-scale power applications, being their typical rated capacities within the range of $10 \mathrm{~kW}-1 \mathrm{MW}$. Its easy design and manufacturing and also the low tar content in producer gas are pointed as the main advantages contributing for their widspread. However, this type of gasifiers presents some drawbacks, such as grate blocking, channeling, and bridging, typically when the feedstock presents low bulk density and are only suitable for feedstock with low moisture content Thus, as already mentioned previously, the low tar producer gas is 

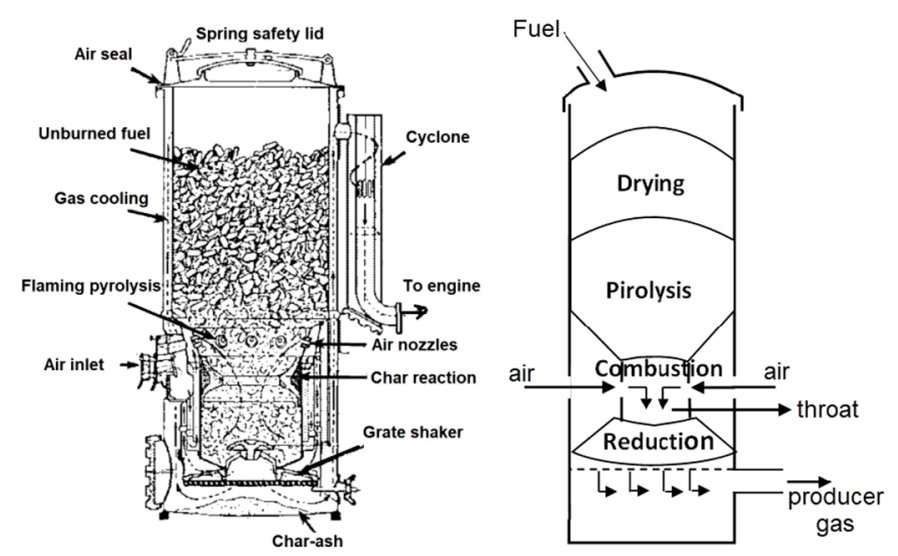

Fig. 1. Downdraft gasifiers - Imbert type [28].

highlighted as the key feature contributing to the wedespread of downdraft gasifiers for small-scale power generation, in particular, when the producer gas is intended to feed the ICE [27].

Imbert gasifier is the most used type of downdraft gasifiers. It is a closed top gasifier that has a throat in the reactor core, between the zones where de oxidation and reduction reations occours (see Fig. 1). The throat in the gasifier design creates a highly uniform temperature field and better mixing conditions, thus playing an important role in reducing the tar concentration in the producer gas [10]. Therefore, as already mentioned previously, this paper concerns the conceptual framework of the downdraft gasifier imbert type, which is presented in Figure 1.

As it can be observed from Figure 1, the fuel feedstook and air flow move downward and the producer gas exits from the bottom. From the top to the bottom of the gasifier, gasification process comprises four stages: drying, pyrolysis, combustion or partial oxidation and reduction. The air is injected in the reaction zone just above the combustion zone. Heat realesed by the incomplete combustion drives the other three stages.

At the drying stage biomass warms-up in the upper part of the gasifier, evaporating the water present in the biomass' pores and surface, commonly reducing the biomass' moisture content below 5\% [29]. As it come closer to the combustion zone, it follows the pyrolysis stage, which occurs because of biomass warms-up to temperatures above $200{ }^{\circ} \mathrm{C}[9,26]$, in the absence of oxygen. Pyrolysis is a thermal decomposition of the large complex hydrocarbon molecules of biomass that break down into relatively smaller and simpler molecules. The initial product of pyrolysis is made of condensable gases (tars, heavier hydrocarbons, and water) and solid char, whose proportion depends on the nature of biomass and the operating conditions of the process, namely the temperature [9].

During the combustion stage, the volatile materials from biomass get oxide and generate non-condensable gases like $\mathrm{CO}, \mathrm{CO}_{2}, \mathrm{H}_{2}, \mathrm{H}_{2} \mathrm{O}$ and $\mathrm{CH}_{4}$ and heat. In the combustion zone, partial oxidation of char produces carbon monoxide, carbon dioxide, and heat. This stage of gasification is very critical since it decides the quality of the producer gas. Some of the key parameters, such as the pressure and the temperature inside the reactor and the type of gasifying agent play an important role in the yield of producer gas [9].

Below de combustion zone, reduction process occurs during endothermic reactions to generate the combustible gases of the producer gas such as $\mathrm{CO}, \mathrm{H}_{2}$ and $\mathrm{CH}_{4}[9]$.

However, the gasification process produces also undesirable products. Among them, tar contents have been reported as the main difficulty in using producer gas for power generation applications, as already mentioned previously. So, according to [22], the formation of tar particles can be controlled by setting up the adequate temperature conditions allowing the required thermal decomposition in the reduction stage. A temperature of $1000^{\circ} \mathrm{C}$ have been reported suitable to reduce tars, leading to low particulate and tar content in the producer gas suited for small-scale power generation employing the ICE.

Therefore, beyond the biomass characteristics, the quality of the producer gas generated in the gasification process is strongly influenced by both the design and the operating parameters of the gasifier. Among the latter, there are two major parameters that determine the level of quality the producer gas: the equivalence ratio (air volume supplied per kg of biomass fuel and the volume of air which is necessary for stoichiometric combustion) and the hearth load defined as the ratio of the gas production rate $\left(\mathrm{Nm}^{3} / \mathrm{h}\right)$ to the gasifier throat area $\left(\mathrm{cm}^{2}\right)$ [10]. The main output parameters in the gasification process in downdraft gasifiers are the producer gas composition, its calorific value, thermal power of the gasifier and gas yield [10]. Thus, the design approach presented in this paper aims to achieve the typical operation parameters that assure an acceptable level of quality of the producer gas to be used in the ICE.

\subsection{Gasifier sizing}

Sizing the imbert type downdraft gasifier requires to determine its geometric parameters following the gas prodution rate required to feed the ICE, as presented in the following sections.

\subsubsection{Gas production rate and feedstock consumption}

The dimensions of the gasifier are calculated according to the required gas production capacity. The gasifier is intended to supply producer gas to the power generation set equipped with a 4-stroke, spark ignition, internal combustion engine, with a displaced volume, $V_{d}$, of $460 \mathrm{~cm}^{3}$, and running at a constant rotational speed, $n$, of $3000 \mathrm{rpm}$ to assure the electrical power generation with grid frequency of $50 \mathrm{~Hz}$. For this conditions, assuming an engine volumetric efficiency, $\eta_{v}$, of $0.8[30]$, the engine inlet flow of air-fuel mixture, $\dot{V}_{\text {comb. }}$ is mixt. estimated, using equation (1) to be about $33.2 \mathrm{Nm}^{3} / \mathrm{h}$.

$$
\begin{aligned}
& \dot{V}_{\text {comb. }}={ }_{\eta v} \frac{V_{d} \frac{n}{60}}{2} . \\
& \text { mixt. }
\end{aligned}
$$


Table 1. Typical composition of the producer gas.

\begin{tabular}{ll}
\hline Constituents & Percentage \\
\hline $\mathrm{CO}$ & $20 \%$ \\
$\mathrm{H}_{2}$ & $18 \%$ \\
$\mathrm{~N}_{2}$ & $47 \%$ \\
$\mathrm{CH}_{4}$ & $2 \%$ \\
$\mathrm{CO}_{2}$ & $12 \%$ \\
\hline
\end{tabular}

To estimate the producer gas production rate required to supply the ICE it is necessary to estimate the air-fuel mass ratio for a stoichiometric fuel mixture. Since different types of biomass will be used, on which the composition of the production gas depends, and this composition is also dependent on the gasification conditions provided by a particular gasifier, the calculations were performed using the composition approach of dry producer gas based on the values found in literature for wood chips [21-23] considering capacities within the range 15-200 kWe, The typical composition of the wood producer gas is presented in Table 1 .

For this composition it was obtained a relation of $1.1 \mathrm{~mol}$ of air per mole of producer gas, for a stoichiometric combustion, thus requiring a production of $16 \mathrm{Nm}^{3} / \mathrm{h}$ of producer gas to supply the ICE.

\subsubsection{Gasifier geometric parameters}

As already mentioned previously, the development of the downdraft gasifiers design that are presented in the literature are, in general, based on the methodologies described in the SERI report [21]. These methodologies are only applicable to gasifiers with rated powers larger than $10 \mathrm{~kW}$, which are above the one required within the ramewor of this paper. Sutar et al. [23] presented the design and development of a small gasifier, with power below this range. Non-linear extrapolation of curves presented in SERI report were used for the purpose of sizing the downdraft gasifier. The experimental analysis of the developed prototypes revealed a high efficiency of gasifier, what validates the calculation methodology used. Given these results the design of the proposed gasifier prototype was performed following the same guidelines of SERI report and using the data presented by Sutar, in [23], for small power range gasifiers.

The main parameter that determines the range of operation of the gasifier and, from which, its geometric parameters are defined, is the Hearth Load, $B_{h}\left(\mathrm{Nm}^{3} / \mathrm{h} / \mathrm{cm}^{2}\right)$. It is defined as the ratio of the gas production rate $\left(\mathrm{Nm}^{3} / \mathrm{h}\right)$ to the gasifier throat area $\left(\mathrm{cm}^{2}\right)$; some authors use, instead, the Superficial Velocity, $S_{V}$, that corresponds to the same property converting the units to $\mathrm{Nm} / \mathrm{s}\left(S_{V}=2.78 \mathrm{~B}_{\mathrm{h}}\right)$. According to literature the maximum value for Hearth Load should be lower than $0.9 \mathrm{Nm}^{3} / \mathrm{h} / \mathrm{cm}^{2}$ [21]. For higher values it is observed a quality degradation of the producer gas due to charcoal dusting, as a result of excessive flow speed in the

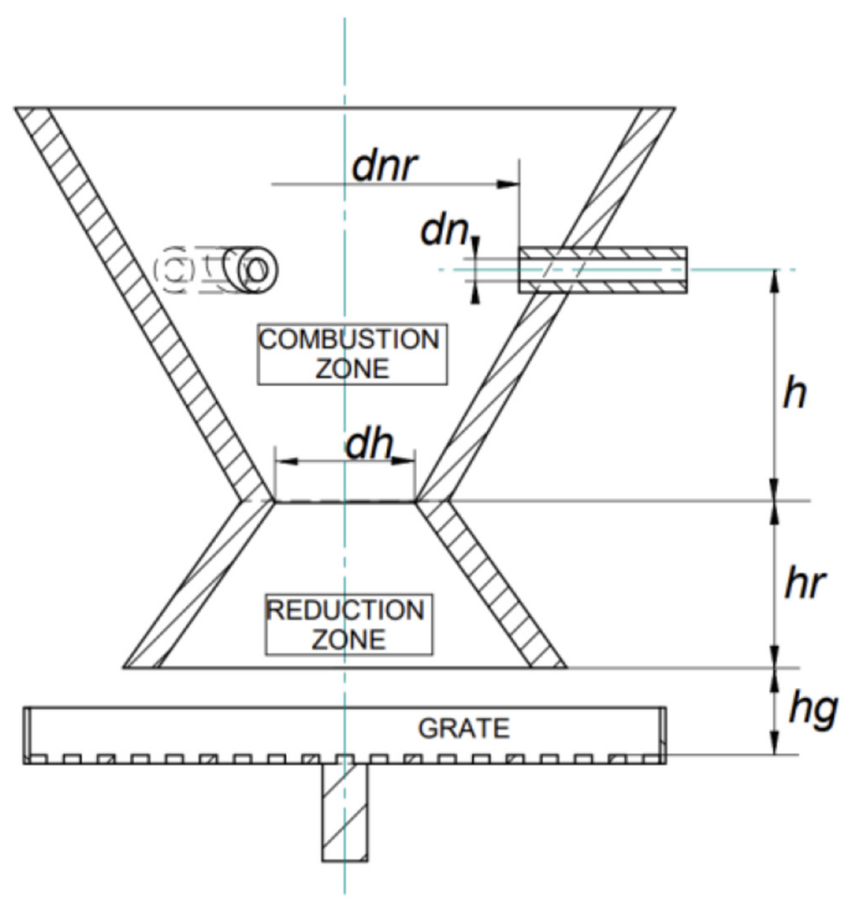

Fig. 2. Geometric parameters of gasifier hearth.

oxidation zone. The decrease in the Hearth Load has the direct consequence of reducing the temperature of the oxidation zone, which results in lower efficiency in tar cracking.

In most gasifiers presented in the literature, the minimum throat load limit, below which the tar concentration is considered too high, is $0.3 \mathrm{Nm}^{3} / \mathrm{h} / \mathrm{cm}^{2}$ [21]. Taking these limits into account, the throat diameter, $d_{h}$, was established in order to obtain a throat load of $0.9 \mathrm{Nm}^{3} / \mathrm{h} / \mathrm{cm}^{2}$ in the maximum operating conditions of the ICE, which corresponds to a production gas flow of 16 $\mathrm{Nm}^{3} / \mathrm{h}$, as calculate before, giving a throat area of $20 \mathrm{~cm}^{2}$, that corresponds to a diameter of $50 \mathrm{~mm}$. Figure 2 shows de main geometrical parameters of the imbert type downdraft gasifier.

Based on the value of throat diameter, $d_{h}$, the distance between throat plane and nozzle plane, $h$, nozzle ring diameter, $d_{r}$, and Nozzle diameter $d_{m}$ were determined according to the throat diameter, using SERI report plots extrapolation for throat values below $70 \mathrm{~mm}$, presented by Sutar in [23], as it can be observed from Figure 3.

The number of suitable nozzles depends on the value of the throat diameter. According o SERI report [22], for a $70 \mathrm{~mm}$ throat diameter, 3 noozle must be used. Preaheting the inlet air before entering the combustion zone contributes to increase the eficiency of the gasification process. Guangul et al. [31], obtained experimental results that showed an increasing of the $\mathrm{H}_{2}$ and $\mathrm{CO}$ in the final composition of producer gas when using preheated inlet air at $500{ }^{\circ} \mathrm{C}$. Taking this into account, a preheating, where air is admitted before being injected into the furnace chamber, was included in the gasifier to be developed. 

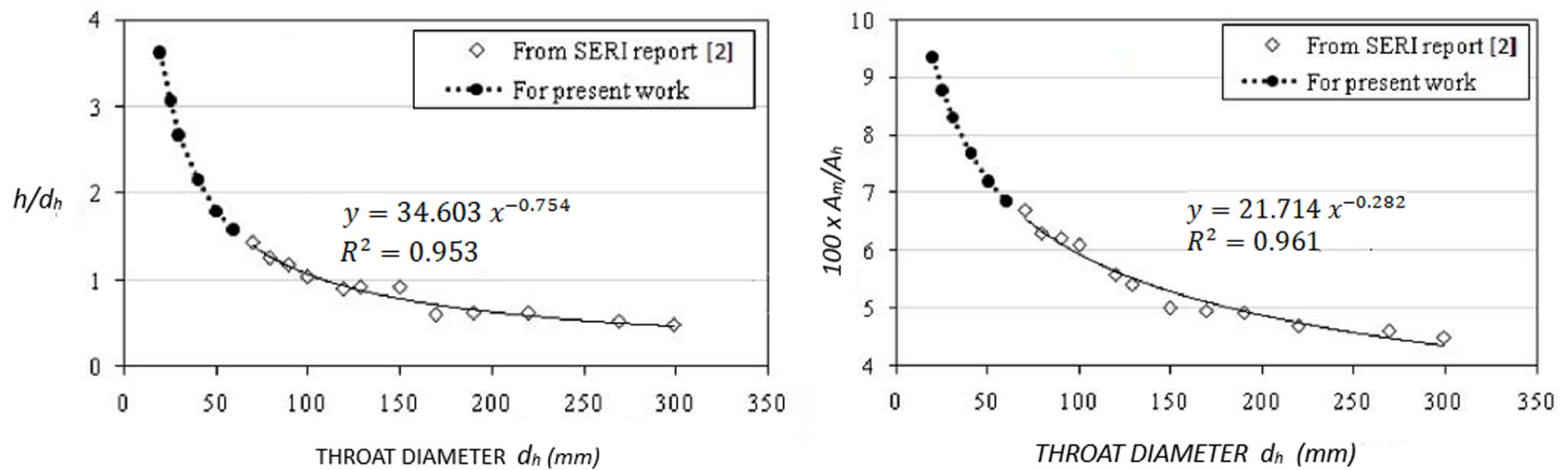

Fig. 3. Plots for design small gasifiers (adapted from [23]).

Table 2. Values of the geometric parameters of the gasifier.

\begin{tabular}{llr}
\hline$d_{h}$ & Throat diameter & $50 \mathrm{~mm}$ \\
\hline$A_{n}$ & Total nozzle area & $14 \mathrm{~mm}^{2}$ \\
$N$ & Number of nozzle & 3 \\
$d_{n}$ & Nozzle diameter & $8 \mathrm{~mm}$ \\
$d_{n r}$ & Nozzle ring diameter & $125 \mathrm{~mm}$ \\
$h$ & Distance from throat to nozzle plane & $90.5 \mathrm{~mm}$ \\
$h_{r}$ & Height of reduction zone & $50 \mathrm{~mm}$ \\
$h_{g}$ & Distance between grate and reduction zone & $30 \mathrm{~mm}$ \\
\hline
\end{tabular}
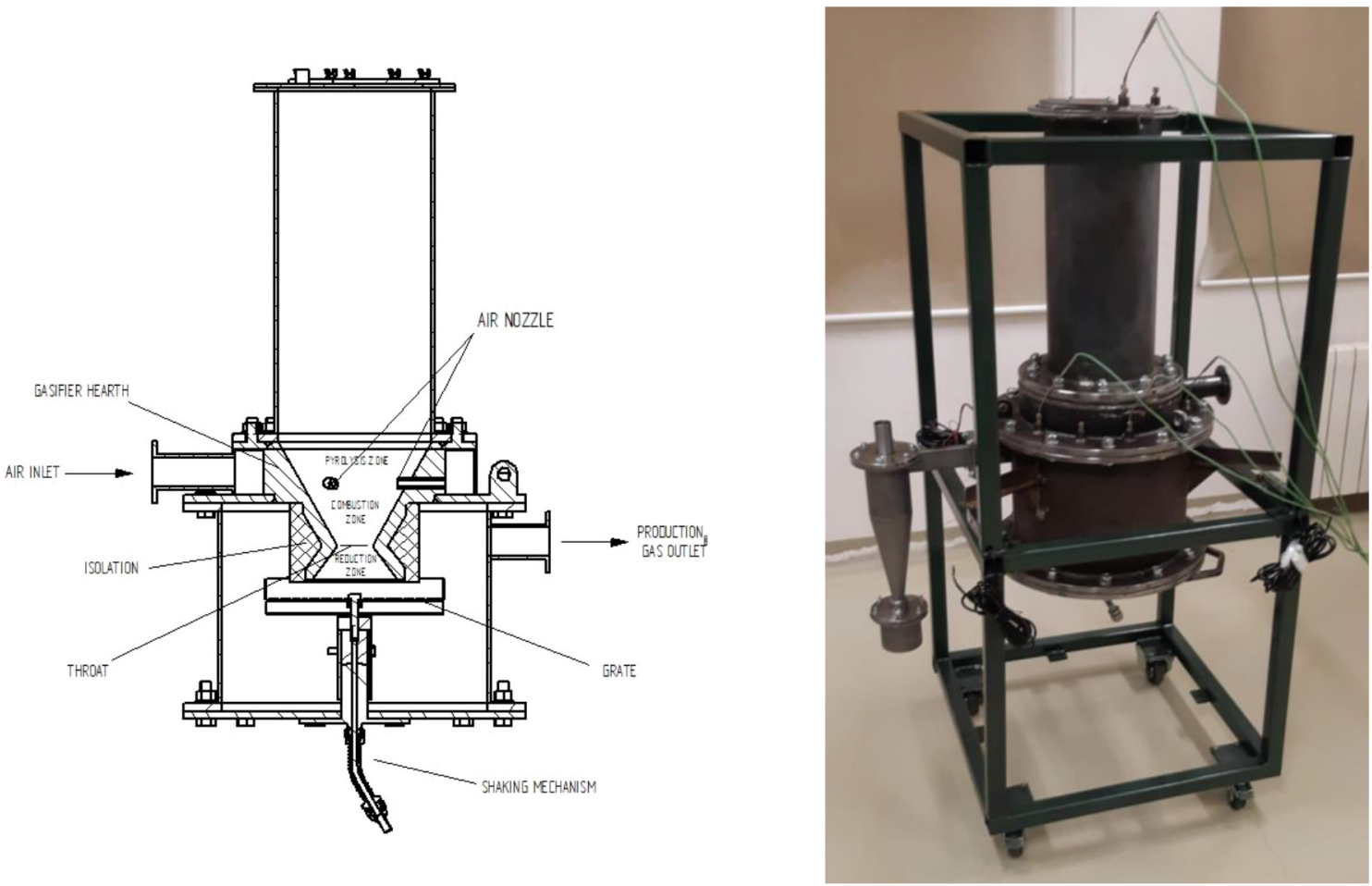

Fig. 4. The Imbert type downdraft gasifier prototype. 
Table 3. Gas quality requirements for ICE [33].

\begin{tabular}{lc}
\hline Particles & $<50 \mathrm{mg} / \mathrm{Nm}^{3}$ \\
Particle size & $<10 \mu \mathrm{m}$ \\
Tar & $<100 \mathrm{mg} / \mathrm{Nm}^{3}$ \\
\hline
\end{tabular}

In order to allow an easier sliding of the biomass in the combustion zone, up to the throat, so reducing the possibility of biomass obstruction, the combustion zone has the shape of a funnel with a great slope, with an angle of $60^{\circ}$.

The zone located below the throat is where de reduction reactions take place. It is made of a cone with downward increasing passage area, with the intend to reduce gas velocity and thereby increase the time of residence of the gas at higher temperatures, and so maximize production of $\mathrm{CO}$ and $\mathrm{H}_{2}$. Following guidelines presented in [21] the cone with height, $h_{r}$, equal to the throat diameter is used. A $45^{\circ}$ angle is used for the cone opening.

At the bottom, located $30 \mathrm{~mm}$ from the reduction cone, there is a grid where the ash separation takes place. As usual in downdraft gasifiers, the grate has a shaking mechanism that, in addition to improving the removal of ash, contributes to prevent blockages of biomass in the upper zones of the gasifier.

The dimensions of the imbert type downdraft gasifier prototype to be developed are apresented in Table 2 .

Figure 4 shows the developed gasifier. The heart of the gasifier is constructed of machined steel. It is insulated with ceramic wool and connected to the outer body of the gasifier in a way that minimizes heat loss to the outside. The air enters the gasifier through a chamber where it is preheated before being injected into the combustion zone by the nozzles. The gasifier grate has a shaking mechanism, with rotating and vertical movements.

\section{Clean-up system for producer gas}

To design the cleaning system it is necessary to determine the magnitude, size and nature of the contaminants allowed to a certain application and then combine that information to choose the equipment for separating impurities [26,32,33]. Then, the order of extraction and temperature along the process must be established.

For an Imbert type downdraft gasifier-based power generation using ICE the main gas quality requirements are presented in Table 3 . Thus, the system must ensure the removal of particles $\left(>300{ }^{\circ} \mathrm{C}\right)$, $\operatorname{tar}\left(>100{ }^{\circ} \mathrm{C}\right)$ and water $\left(30-60{ }^{\circ} \mathrm{C}\right)$ from the gas, in that order and reducing temperatures [34].

The experimental cleaning setup is shown in Figure 5. It was designed in three different main stages. The first stage is composed by a cyclone to remove most of the soot that is collected in a sealed vessel on the base of the cyclone. In this stage, the gas is at temperatures that range from $300{ }^{\circ} \mathrm{C}$ to $500{ }^{\circ} \mathrm{C}$ not allowing the condensation of the tars contained into the gas stream so as not to dirty the gasifier with sticky material. The second stage is a cooling process, in a heat

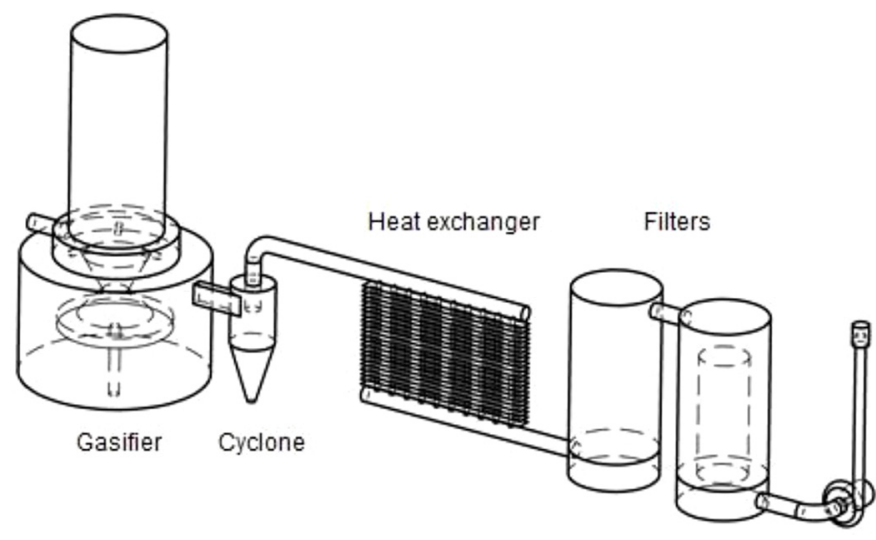

Fig. 5. The gasifier and gas cleaning system.

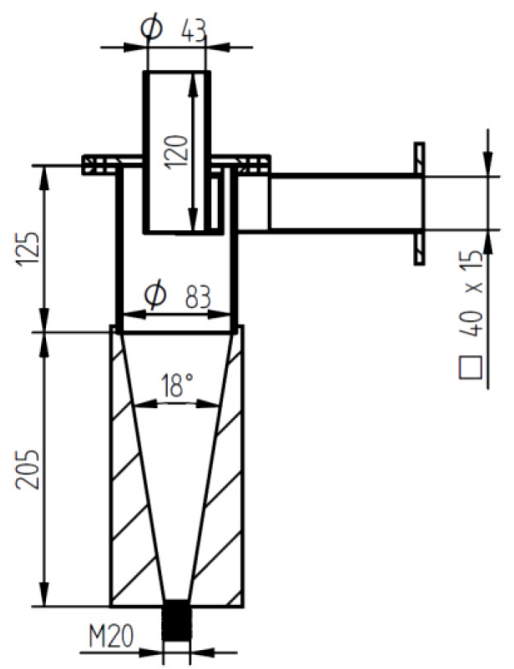

Fig. 6. Cyclone main dimensions ( $\mathrm{mm})$.

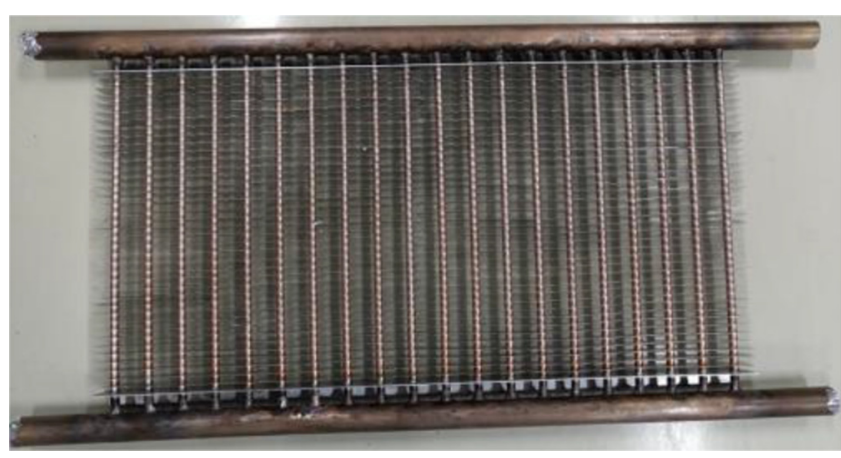

Fig. 7. Compact heat exchanger.

exchanger, to low the gas temperature and eliminate condensed tars. The third stage consists of filtering the producer gas, through two filters. The first is a container filled with biomass, whose objective is to retain water vapor and tar. The advantage of using this type of filter is that this biomass can, after dried, be used in the gasifier 
recycling the tar retained. The second one is a polypropylene cartridge filter that is used to eliminate smaller particles and reinforce the cleaning of the gas.

\subsection{Cyclone}

The cyclone was designed to separate solids (particles) from a gaseous stream. The density of the particles on the downdraft gasifiers exit is, usually, greater than $50 \mathrm{mg} / \mathrm{Nm}^{3}$ and the gas produced is a mixture of compounds at temperatures above $300{ }^{\circ} \mathrm{C}$. The flow rate of the gas stream that passes through the cyclone is $33.6 \mathrm{~m}^{3} / \mathrm{h}$, considering the gas temperature at $300{ }^{\circ} \mathrm{C}$. The size of the particles depends on the factors associated with the quality of the produced gas, however for this application it is necessary to eliminate particles with sizes less than $1 \mu \mathrm{m}$ to over $100 \mu \mathrm{m}[35,36]$. As $45 \%$ of the particles are below $10 \mu \mathrm{m}$, a high efficiency cyclone is required. To calculate the diameter of the cyclone, an inlet velocity is selected in the range of 12 to $17 \mathrm{~m}^{3} / \mathrm{s}$. For this case an input speed of $15 \mathrm{~m} / \mathrm{s}$ was selected. With this value, the diameter of the cyclone and the other dimensions can be determined based on the relationships established for the families of cyclones.

The high-efficiency design model was considered to size the cyclone. The diameter $d$ was calculated, which can be expressed as a function of the flow of gas $Q$ that enters the cyclone. With the value of the diameter, the table of multiplicative factors corresponding to the different dimensions of the cyclone was used [22,37]. The dimensions obtained from the cyclone used in this project are shown in Figure 6.

\subsection{Heat exchanger}

To remove a high content of tar in the producer gas generated from biomass gasification, it is necessary to cool the producer gas to condense tar and subsequently filter droplets. A compact heat exchanger, constituted by 20 tubes with $3 / 8$ / of diameter mounted in parallel between the inlet and outlet manifolds, with plate fins, is used, as it can be observed in Figure 7.

From an estimate of the inlet temperature of the production gas in the heat exchanger of $400{ }^{\circ} \mathrm{C}$, the heat exchanger was sized to reduce the temperature until about $60{ }^{\circ} \mathrm{C}$, which corresponds to a heat dissipation rate of about $1.5 \mathrm{~kW}$. The obtained heat transfer area is approximately $2.2 \mathrm{~m}^{2}$.

\subsection{Filters}

The generated producer gas is sent to the compact biomass filter to remove the greater amount of particles that could not be eliminated in the cyclone and tars that condense at low temperatures [35]. A characteristic of this filter is the potential of the biomass to be reused in the gasifier. When leaving the biomass filter the gas produced passes through a cartridge filter, at the end of the cleaning system, that is used as auxiliary protection to the engine. The cartridge type filter was selected because it has a larger filtrate area and higher permeability compared to the bag filters that are traditionally used in these applications. A polyester filter with a hydrophobic coating was chosen considering his resistance to the temperature.

\section{Preliminary experimental results}

Preliminary experimental tests were performed to observe the temperature achieved along the process and to identify eventually major problems in the gasification process. To avoid the formation of large amounts of tar during the warm-up period, the gasifier was filled with charcoal in the reduction and combustion zones and charged with biomass on the top. At this early stage of experimental tests, it was decided to use pellets as biomass feedstock. The temperatures of the gasification process were measured using thermocouples positioned inside the gasifier, in the pyrolysis, combustion and reduction zones, about $2 \mathrm{~cm}$ from the gasifier wall. The intake air flow was measured through a pitot tube.

The air flow was established experimentally, during the tests, seeking a temperature in the combustion zone of about $1200^{\circ} \mathrm{C}$, which corresponds which is near the highest values for this phase of the gasification process found in literature.

Despite the high temperatures reached in the combustion zone, the temperatures recorded in the reduction zone were around $600{ }^{\circ} \mathrm{C}$, that is significantly lower than the desired temperature, which is recommended to be above $1000{ }^{\circ} \mathrm{C}$. This fact reveals too high heat losses due to poor thermal insulation of the reactor walls. Another problem observed during the realization of the experimental tests was the obstruction of the biomass flow due to the bridging effect above the combustion zone, even though the large taper angle of the throat and the use of a shaking grate.

These results highlight significant drawbacks of the developed Imbert type downdraft gasifier prototype, making it unfeasible to meet the stringent requirements identified within the framework of its intended application, focusing, specially the producer gas quality within the acceptable levels required by the ICE due to the high tar concentration levels. Therefore, further developments are required to overcome the above-mentioned drawbacks. Based on the previous experience acquired during both the development and the experiments of the Imbert type downdraft gasifier prototype, further developments comprise the development of an improved gasifier prototype exploiting alternative design solutions for downdraft gasifiers and to improve the reactor thermal insulation by using refractory ceramic material of low density in the construction of the internal walls of the reactor. To overcome the bridging effect, a downdraft gasifier without throttling will be adopted, with a constant cross section throughout, and double air stage.

\section{Conclusion}

This paper presents a gasification system prototype for an Imbert type downdraft gasifier, addressing the development of the gasifier and the cleaning system of the producer gas. It is intended to be integrated in a pilot small-scale power generation system to produce syngas to feed the ICE. The design of the gasifier complies with the established parameters and is sized following a methodology based on the available literature. However, it was necessary to 
extrapolate the data to apply the sizing methodology to a small-scale gasifier.

Producer gas cleaning units were selected regarding their efficiency to reach gas quality requirement for use in ICE. A special emphasis on tar and particle removals from small scale gasifier was developed based on treatment efficiency.

The results obtained during the realization of the preliminary experimental tests using the Imbert type downdraft gasifier prototype allow to verify two main drawbacks: obstruction of the biomass flow due to the bridging effect and high heat losses due to poor thermal insulation of the reactor walls. Consequently, the temperature is lower than the recommended one for small-scale power generation applications with ICE since the producer gas presents high tar concentration levels. These drawbacks difficult the effective integration of the developed prototype in small scale power applications using the ICE within the framework of the SUBe Project. Therefore, further developments are required to overcome the above-mentioned drawbacks, aiming to improve the temperature profile within the gasifier and to prevent the bridging effect.

\section{References}

1. B. Buragohain, P. Mahanta, V.S. Moholkar, Biomass gasification for decentralized power generation: the Indian perspective, Renew. Sustain Energy Rev. 14, 73-92 (2010)

2. L.I. Chaves, M.J. Silva, S.N.M. Souza, D. Secco, H.A. Rosa, C.E.C. Nogueira, E.P. Frigo, Small-scale power generation analysis: downdraft gasifier coupled to engine generator set, Renew. Sustain Energy Rev. 58, 491-498 (2016)

3. F.O. Resende, V. Silva, M. Mendonça, A. Barbosa, P. Brito, A. Almeida, H.T. Gomes, Using biomass gasification for small scale power generation systems: specifications of the conceptual framework, in ICRERA 2019. 8th Int. Conf. Renew. Energy Res. Appl. Novemb. 3-6, 2019, Brasov/ Romania (2019), pp. 439-444, doi 10.1109/ ICRERA47325.2019.8996828

4. L.M.C. Pinto, S. Sousa, M. Valente, From renewable energy source to fire prevention tool: are individuals willing to pay for forest biomass? in 4th Annu. APEEN Conf. 2019. Enerrgy Demanda_Side Manag. Electr. Mark. Univ. Beira Inter. Covilhã, Port. Oct. 17-18 (2019) 1-7

5. F.O. Resende, V. Silva, M. Mendonça, A. Barbosa, P. Brito, A. Almeida, J. Azevedo, H.T. Gomes, Small scale power generation unit using biomass gasification: the SUBe Project, in Congresso Ibero-americano de Empreendedorismo, Energia Meio Ambiente e Tecnologia (2019) 11

6. H. Jeanmart, Simulation of biomass gasifier engine system, Prog. Energy Combust. Sci. 46, 1-8 (2015)

7. H. Knoef, Handbook of Biomass Gasification, BTG Gr., vol. 2012, no. December, p. 378, 2005.

8. S. Mani, L.G. Tabil, S. Sokhansanj, Effects of compressive force, particle size and moisture content on mechanical properties of biomass pellets from grasses, Biomass Bioenergy 30, 648-654 (2006)

9. S.K. Sansaniwal, K. Pal, M.A. Rosen, S.K. Tyagi, Recent advances in the development of biomass gasification technology: a comprehensive review, Renew. Sustain. Energy Rev. 72, 363-384 (2017)

10. J.D. Martínez, K. Mahkamov, R.V. Andrade, E.E. Silva Lora, Syngas production in downdraft biomass gasifiers and its application using internal combustion engines, Renew. Energy 38, 1-9 (2012)

11. P. Raman, N.K. Ram, Design improvement and performance testing of biomass gasifier based electric power generation system, Biomass Energy 56, 555-571 (2013)

12. L. Van de steen, J.P. Tagustchou, F. Mermoud, E. Martin, S. Salvador, A new experimental continuous fixed bed reactor to characterize wood char gasification, Fuel 89, 3320-3329 (2010)

13. P.N. Sheth, B.V. Babu, Production of hydrogen energy through biomass (waste wood) gasification, Hydrogen Energy 35, 10803-10810 (2010)

14. Z.Q. Ma, Y.M. Zang, Q.S. Zang, Y.B. Qu, J.B. Zhou, H.F. Qin, Design and experimental investigation of a $190 \mathrm{kWe}$ biomass fixed bed gasification and polygeneration pilot plant using a double air stage downdraft approach, Energy 46, 140-147 (2012)

15. J.F. Pérez, A. Melgar, P.N. Benjumia, Effect of operating and design parameters on the gasification/combustion process of waste biomass in fixed bed downdraft reactors: an experimental study, Fuel 96, 478-496 (2012)

16. A.K. Sharma, Experimental study on $75 \mathrm{kWth}$ downdraft (biomass) gasifier system, Renew. Energy 34, 1726-1733 (2009)

17. G. Ferquiang, Y. Dong, L. Dong, C. Guo, Effect of design and operating parameters on the gasification process of biomass in a downdraft fixed bed: an experimental study, Hydrogen Energy 39, 5625-5633 (2014)

18. L. Mentuori, C. Vargas-Salgado, M. Alcázar-Ortega, Impact of the throat sizing on the operating parameters in an experimental fixed bed gasifier: analysis, evaluation and testing, Renew. Energy 83, 615-625 (2015)

19. M. Asadullah, Technical challenges of utilizing biomass gasification gas for power generation: an overview, Energy Technolog. Policy 11, 137-143 (2013)

20. L.E. Taba, M.F. Irfan, W.A.M. Daud, The effect of temperature on various parameters in coal, biomass and co-gasification: a review, Renew. Sustain. Energy Rev. 16, 5584-5596 (2007)

21. T.B. Reed, D. Jantzen, Generator Gas - The Swedish Experience from 1939-1945, Solar Energy Research Institute, Colorado, USA (1979)

22. T.B. Reed, A. Das, Handbook of Biomass Downdraft Gasifier Engine Systems, SERI . U.S. Dep. Energy (1988) p. 148

23. K.B. Sutar, S. Kohli, M.R. Ravi, Design, development and testing of small downdraft gasifiers for domestic cookstoves, Energy 124, 447-460 (2017)

24. U. Shrinivasa, H.S. Muhunda, Experience with gasifiers for 3,7 kW engines, Ambio. Energy Dev. Ctries 14, 275-279 (1985)

25. U. Shrinivasa, H.S. Muhunda, Wood gas generators for small power (5 hp) requirements, Sadhana 7, 137-154 (1984)

26. A.A.P. Susastriawan, H. Saptoadi, Purnomo, Small-scale downdraft gasifiers for biomass gasification: a review, Renew. Sustain. Energy Rev. 76, 989-1003 (2017)

27. R. Bates, K. Dölle, Syngas use in internal combustion engines - a review, Adv. Res. 10, 1-8 (2017)

28. H. Rohracher, J. Ahrenfeldt, R.L. Bain, B. van de Beld, S.C. Bhattacharya, H. Boerrigter, Handbook Biomass Gasification (GasNEt, Netherlands, 2005)

29. B. Prabir, Biomass Gasification and Pyrolysis, Practical Design and Theory (Elsevier, Burlington, 2010) 
30. J. Heywood, Internal Combustion Engine Fundamentals (2005)

31. F.M. Guangul, S.A. Sulaiman, A. Ramli, Study of the effects of operating factors on the resulting producer gas of oil palm fronds gasification with a single throat downdraft gasifier, Renew. Energy (2014)

32. N. Abdoulmoumine, S. Adhikari, A. Kulkarni, S. Chattanathan, A review on biomass gasification syngas cleanup, Appl. Energy 155, 294-307 (2015)

33. P.J. Woolcock, R.C. Brown, A review of cleaning technologies for biomass-derived syngas, Biomass Bioenergy 52, 54-84 (2013)
34. P. De Filippis, M. Scarsella, B. De Caprariis, R. Uccellari, Biomass gasification plant and syngas clean-up system, Energy Proc. 75, 240-245 (2015)

35. P. Hasler, T. Nussbaumer, Gas cleaning for IC engine applications from fixed bed biomass gasification, Biomass Bioenergy 16, 385-395 (1999)

36. Prabhansu, M.K. Karmakar, P. Chandra, P.K. Chatterjee, A review on the fuel gas cleaning technologies in gasification process, J. Environ. Chem. Eng. 3, 689-702 (2015)

37. A.J. Macintyre, Ventilação Industrial e Controle da Poluição (2003)

Cite this article as: Miguel Mendonça, Victor Mantilla, João Patela, Valter Silva, Fernanda Resende, Design and experimental tests of an Imbert type downdraft gasifier prototype and clean-up system for small-scale biomass-based power generation, Renew. Energy Environ. Sustain. 7, 10 (2022) 